\title{
Effect of Rhizophagus intraradices on growth and physiological performance of Finger Millet (Eleusine coracana L.) under drought stress
}

\author{
Jaagriti Tyagi $1^{*}$, Neeraj Shrivastava ${ }^{1}$, A. K. Sharma ${ }^{2}$, Ajit Varma ${ }^{1} \&$ Ramesh Namdeo Pudake $^{3^{*}}$ \\ ${ }^{1}$ Amity Institute of Microbial Technology, Amity University Uttar Pradesh, Sector 125, Noida Express Way, Noida, U.P 201 313, India \\ ${ }^{2}$ Department of Biological Sciences, College of Basic Sciences and Humanities, G. B. Pant University of Agriculture and Technology, Pantnagar \\ 263 145, India \\ ${ }^{3}$ Amity Institute of Nanotechnology, Amity University Uttar Pradesh, Sector 125, Noida Express Way, Noida, U.P 201 313, India \\ *Email: jtyagi@amity.edu, rnpudake@amity.edu
}

\section{ARTICLE HISTORY}

Received: 20 April 2021

Accepted: 11 September 2021

Available online: 30 September 2021

\section{KEYWORDS}

Antioxidant

Drought

Finger millet

Mycorrhiza

ROS

\section{ABSTRACT}

Under abiotic stress conditions, arbuscular mycorrhizal (AM) fungi help plants by improving nutrient and water uptake. Finger millet (Eleusine coracana L.) is an arid crop having soils with poor water holding capacity. Therefore, it is difficult for the plants to obtain water and mineral nutrients from such soil to sustain life. To understand the role of mycorrhizal symbiosis in water and mineral up-take from the soil, we studied the role of Rhizophagus intraradices colonization and its beneficial role for drought stress tolerance in finger millet seedlings. Under severe drought stress condition, AM inoculation led to the significant increase in plant growth (7\%), phosphorus and chlorophyll content (29\%). Also, under drought stress the level of osmolytes such as proline and soluble sugars were found to be increased in AM inoculated seedlings. Under water stress, the lipid peroxidation in leaves of mycorrhized seedlings was reduced by $29 \%$. The flavonoid content of roots in AM colonized seedlings was found $16 \%$ higher compared to the control, whereas the leaves were accumulated more phenol. Compared to the control, ascorbate level was found to be $25 \%$ higher in leaf tissue of AM inoculated seedlings. Moreover, glutathione (GSH) level was also increased in mycorrhiza inoculated seedlings with a maximum increment of $182 \%$ under severe stress. The results demonstrated that AM provided drought tolerance to the finger millet seedlings through a stronger root system, greater photosynthetic efficiency, a more efficient antioxidant system and improved osmoregulation.

\section{Introduction}

Finger millet (Eleusine coracana L.) is grown worldwide in more than $4 \mathrm{~m} \mathrm{ha}$, and is the staple food for millions of people in less developed countries of Africa and Asia (1). It is rich in calcium, phosphorus, iron and amino acids like cysteine, tyrosine, tryptophan and methionine (2), which are crucial for human health. This plant is grown in semiarid and tropical regions where the soils are suffering from the deficiency of nutrients, low precipitation, high evapotranspiration rates and other restrictive environmental factors. Drought is one of the most challenging threat that may cause serious losses in crop yield, and by 2025 up to $30 \%$ of the global crop yield losses are expected due to drought (3). Drought conditions threat crop productivity with finger millet no exception to it, so there is an urgent need to find solutions which can provide an optimum yield under the drought stress.
Many studies have been focused to understand the molecular and physio-chemical mechanism of drought tolerance in crop plants. Under water stress, various biochemical reactions occur in plants like reduction in chlorophyll content and increase in the production of reactive oxygen species (ROS) (4). Like other environmental stresses, the homeostasis between production and detoxification of ROS in plants affect the development and growth under water stress (5). These irregularities cause several cellular damages such as oxidative damage of proteins, nucleic acids and lipids $(6,7)$. Water limitation influence many physiological processes by altering the production and accumulation of secondary metabolites like phenols and flavonoids (8). These are efficient chain-breaking antioxidants that can inhibit lipid peroxidation and reduce oxidative damage during water stress and helps in scavenging of ROS (9).

(C) Tyagi et al (2021). This is an open-access article distributed under the terms of the Creative Commons Attribution License, which permits unrestricted use, distribution and reproduction in any medium, provided the original author and source are credited (https://creativecommons.org/licenses/by/4.0/). 
Recently the use of arbuscular mycorrhiza (AM) has received increased attention in crop physiology, because mycorrhized plants are generally more tolerant to abiotic stresses than non-mycorrhized plants. AM symbiosis protects the host plants against the harmful effects through different physiological mechanisms of drought avoidance (10-11). Promotion of plant growth under stress is due to establishment of the extensive hyphal networks, secretion of biomolecules like glomalin for improving soil structure, and increasing water and nutrient uptake (12). Moreover, due to the presence of extra radical mycelium (ERM) the plant can effectively absorb water from the tightly held soil water around the roots, thus increase the soil-root hydraulic conductance (13). Previous reports have suggested that the AM symbiosis can help plant to achieve drought tolerance due to physical, nutritional, physiological and cellular processes (14). The effect of AM symbiosis for nutrient absorption and other growth parameters attributes in finger millet has been studied in recent past (15-16). But the studies on AM symbiosis to mitigate abiotic stress in this millet crop are very less. In the previous study, plant growth promoting rhizobacteria (PGPR) and AM symbiosis was evaluated for reducing the effects of water stress (17). They found that the symbiosis of PGPR along with AM fungi has positive role on plant growth parameters during watered and water deficient conditions. But the underlying biochemical mechanism behind this association was not revealed, as only proline and superoxide dismutase (SOD) content were estimated

In the present research AMF Rhizophagus intraradices (now known as Rhizophagus irregularis) was used. Recently, the genome of this AMF fungi is sequenced because (i) it is the most studied AM fungus in laboratories; (ii) it has high sporulation capacity, thus provides high fungal biomass (iii) its genome size is lower than that of many other AM fungal species (18). The aim of the present study is to evaluate physiological and biochemical impacts of symbiotic association under drought in depth and the findings are reported here.

\section{Materials and Methods}

\section{Plant material, soil and drought stress treatment}

Finger millet seeds (cv. Ragi Korchara) were provided by GB Pant Agriculture University, Pantnagar, Uttarakhand. Seeds were surface sterilized with $2 \%$ of sodium hypochlorite for 2 min followed by washing with sterilized distilled water for three times. The sterilized seeds were germinated in Petri plates containing sterilized wet filter paper with distilled water at $27 \pm 2{ }^{\circ} \mathrm{C}$. Three days old germinated seeds with uniform length of radical were transferred to pots (1.5 l size, 2 seedlings /pot) with the mixture of double autoclaved sand and soil in 1:1 proportion. The potting mixture was analysed for various soil parameters at Soil Testing Laboratory, Indian Agriculture Research Institute (IARI), New Delhi with standard established methods. The results of analysis showed that, it contained $0.10 \%$ organic carbon (OC),
$4.11 \mathrm{~g} \mathrm{~kg}^{-1}$ of $\mathrm{P}$ and $18.57 \mathrm{~g} \mathrm{~kg}^{-1} \mathrm{~K}, \mathrm{pH} 8.33$, electrical conductivity (EC) $0.34 \mathrm{ds} / \mathrm{m}$ and field capacity (FC) of $33 \%$.

The seedlings with and without inoculation of AM fungus- Rhizophagus intraradices were exposed to drought stress conditions. First, the starter culture of AM fungi was maintained and multiplied with maize seedlings in pots with autoclaved soil and sand in 1:1 ratio. The numbers of spores present in the inoculum were counted and $2 \mathrm{~g}$ of inoculum (50 spores $\mathrm{g}^{-1}$ ) was used by making holes at the immediate vicinity of the germinated seeds. For control treatment, microbial wash from same quantity of inoculum was added, which was prepared by filtering AM inoculum through Whatman filter paper. Seedlings were grown in glass house under controlled conditions with $28{ }^{\circ} \mathrm{C}$ temperature, $16 \mathrm{~h}$ photoperiod (2500 lx) and 60-70\% relative humidity. The experiment was carried out in a completely randomized design with three replications of each treatment.

The water stress was created by regular monitoring of water status according to the predecided treatment. The plants were exposed to mildstress (60\% FC) and severe stress ( $40 \%$ FC) by allowing soil to dry to the required level. When the water status reached to desired level, the water lost by evapotranspiration was adjusted by re-watering. Field capacity of soil was estimated by gravimetric method (19). Initially, the seedlings were irrigated with tap water to $100 \%$ field capacity (FC) for one month. Later, water stress treatments were given by maintaining the soil water status to $100 \%$ (wellwatered), $60 \%$ (mild stress) and $40 \%$ (severe stress) of FC. To achieve the soil water status at $60 \%$ and $40 \%$ FC, pots were allowed to dry to reach the required level. During stress period of 10 days, the pots were weighed daily and the amount of water lost by evapotranspiration replenished by re-watering After 10 days of drought stress, seedlings were harvested by firmly shaking the pots to loosen the soil and then tilting the pots at $<45^{\circ}$ of angle for smoothly pulling out the intact soil ball from the pots, without damaging the roots. For agronomical and biochemical estimation, treated and control samples were stored separately in plastic bags. The short duration storage was done at $4^{\circ} \mathrm{C}$ for physiological observation and for biochemical analysis the samples were stored at $80^{\circ} \mathrm{C}$.

\section{Morphological parameters of finger millet seedlings}

After drought treatment, randomly selected seedlings from each treatment were used to measure the plant height, number of leaves in plant and root length. Shoot and root dry weights of plant was estimated after drying at $75{ }^{\circ} \mathrm{C}$ for $48 \mathrm{~h}$ in oven until a constant weight was obtained. Phosphorus content in seedlings of all the treatments was measured in oven dried samples (20).

\section{Estimation of root colonization}

Mycorrhizal colonization percentage in roots was measured according to the established method (21). Briefly, after washing with distilled water, roots were cleared in $5 \% \mathrm{KOH}$ solution at $95{ }^{\circ} \mathrm{C}$ for $1 \mathrm{~h}$, and then treated with $5 \% \mathrm{HCl}$ for $10 \mathrm{~min}$. The cleared roots 
were stained with $0.05 \%$ Trypan blue-lactic acid solution $(\mathrm{v} / \mathrm{v})$. The colonization frequency was estimated by grid-line intersect method (21) and three replicates per treatment were used for the measurements.

\section{Chlorophyll content in leaves}

Chlorophyll content in the leaves was estimated by adding $0.1 \mathrm{~g}$ of finely chopped leaf samples in $7 \mathrm{ml}$ of dimethyl sulfoxide (DMSO) followed by incubation in water-bath at $65{ }^{\circ} \mathrm{C}$ for $30 \mathrm{~min}$ until green tissues turned colourless (22). The cooled samples were filtered, and volume was made up to $10 \mathrm{ml}$ by adding more DMSO. After vortexing for few seconds, UV light absorption was measured using spectrophotometer (UV/Vis-1800, Shimadzu, Japan) at 645 and $663 \mathrm{~nm}$. DMSO without any plant sample was used as a control. The amount of total chlorophyll present in DMSO extract was measured as mg chlorophyll $\mathrm{g}^{-1}$ tissue according to the following formula (23).

$$
\text { Total Chl }\left(\mathrm{g} \mathrm{l}^{-1}\right)=0.0202 \times \mathrm{A}_{645}+0.00802 \times \mathrm{A}_{663}
$$

\section{Determination of proline content}

The proline content in finger millet tissues was determined by previously described method (24). Briefly, for this $0.1 \mathrm{~g}$ of fresh plant tissue was homogenized in $1.5 \mathrm{ml}$ of $3 \%$ sulfosalicylic acid and centrifuged for $5 \mathrm{~min}$ at $13000 \mathrm{rpm}$. The supernatant of around $300 \mu \mathrm{l}$ was transferred into a new tube followed by the addition of $2 \mathrm{ml}$ each of acid ninhydrin [1.25 g of ninhydrin in $20 \mathrm{ml}$ of phosphoric acid $(6 \mathrm{M})$ and $30 \mathrm{ml}$ of glacial acetic acid] and glacial acetic acid. The mixture was kept in water bath (100 $\left.{ }^{\circ} \mathrm{C}\right)$ for $1 \mathrm{~h}$, and immediately cooled on ice. Toluene (1 ml) was added to the reaction and vigorously mixed for a few seconds. Toluene containing chromophore layer was removed from the aqueous phase and kept at room temperature. Absorbance of each sample was measured in spectrophotometer at $520 \mathrm{~nm}$ against Toluene blank. The standard curve was used to calculate the concentration of proline, with three independent replicates.

\section{Estimation of total soluble sugar (TSS)}

Total soluble sugars from the finger millet tissues were extracted and analysed according to the method reported earlier (25). In short, $0.1 \mathrm{~g}$ of tissue was homogenised in $2 \mathrm{ml}$ of $80 \%(\mathrm{v} / \mathrm{v})$ ethanol, and vortexed for few seconds. The homogenates were allowed to stand at room temperature for $30 \mathrm{~min}$ and centrifuged at $10000 \mathrm{rpm}$ for $20 \mathrm{~min}$. The resulted supernatants were stored at $4{ }^{\circ} \mathrm{C}$ until further analysis. Later, $5 \mathrm{ml}$ of supernatant was mixed with $3 \mathrm{ml}$ of freshly prepared anthrone reagent (200 mg anthrone, $100 \mathrm{ml}$ of $72 \%$ sulphuric acid), and followed by the incubation in the water bath at $100{ }^{\circ} \mathrm{C}$ for $10 \mathrm{~min}$, after which the absorbance was measured at $620 \mathrm{~nm}$. The TSS was determined using glucose as a standard and expressed as $\mathrm{mg} \mathrm{g}^{-1}$ fresh weight (FW) of plant tissue.

\section{Measurement of lipid peroxidation}

Measurement of lipid peroxidation was evaluated in terms of malondialdehyde (MDA) content as reported (26). The analysis contained $1.0 \mathrm{~g}$ of fresh grinded tissue mixed with $5 \mathrm{ml}$ solution of $0.6 \%$ Thiobarbituric acid (TBA) in $10 \%$ Trichloroacetic acid
(TCA). The mixture was subsequently centrifuged at $12000 \mathrm{rpm}$ for $20 \mathrm{~min}$, and $2 \mathrm{ml}$ of the resultant supernatant was supplemented with $2 \mathrm{ml}$ of $0.6 \%$ thiobarbituric acid (TBA) in $10 \%$ TCA. The reaction was incubated in boiling water for $15 \mathrm{~min}$, and then quickly cooled on ice. Afterward it was centrifuged at $12000 \mathrm{rpm}$ for $10 \mathrm{~min}$ again, and the absorbance of the supernatant was measured at 450, 532 and $600 \mathrm{~nm}$.

The MDA content was calculated on a fresh weight bases using the below mentioned formula

$$
\mu \mathrm{M} \text { MDA g-1 of FW }=6.45 \times\left(\mathrm{OD}_{532}-\mathrm{OD}_{600}\right)-0.56 \times \mathrm{OD}_{450} \text {. }
$$

\section{Estimation of hydrogen peroxide content}

Method suggested earlier was used for the estimation of hydrogen peroxide $\left(\mathrm{H}_{2} \mathrm{O}_{2}\right)$ content (27). Briefly, $0.5 \mathrm{~g}$ of plant tissue was homogenized in $0.1 \%$ TCA, and homogenized mixture was centrifuged at $12000 \mathrm{rpm}$. Later, the reaction mixture containing $0.5 \mathrm{ml}$ of 10 $\mathrm{mM}$ potassium phosphate buffer ( $\mathrm{pH}$ 7.0) and $1 \mathrm{ml}$ of potassium iodide solution were thoroughly mixed to $0.5 \mathrm{ml}$ of the supernatant and absorbance was measured at $390 \mathrm{~nm}$. A standard curve plotted using a known concentration of $\mathrm{H}_{2} \mathrm{O}_{2}$, was used to calculate the content of $\mathrm{H}_{2} \mathrm{O}_{2}$.

\section{Estimation of antioxidant compounds- Glutathione, Ascorbate, Phenols and Flavonoids}

Glutathione (GSH) content was determined by following the method suggested in the previous report (28). Briefly, plant tissue $(0.1 \mathrm{~g})$ was homogenized in 1 $\mathrm{ml}$ of $5 \%$ TCA under cold condition and centrifuged at $10000 \mathrm{rpm}$ for $10 \mathrm{~min}$. $100 \mu \mathrm{l}$ of the supernatant was made up to $1.0 \mathrm{ml}$ with $100 \mathrm{mM}$ potassium phosphate buffer ( $\mathrm{pH}$ 7.0) and $2 \mathrm{ml}$ of 5,5-dithio-bis- (2nitrobenzoic acid) (DTNB) solution. The resultant mixture was vortexed thoroughly for few seconds and incubated for $10 \mathrm{~min}$ for colour development. The intensity of the yellow colour developed was measured at $412 \mathrm{~nm}$ with spectrophotometer. The values were expressed as $\mathrm{nM}$ GSH g-1 plant sample. GSH standards were prepared for concentrations ranging between 0 and $50 \mathrm{ng} \mathrm{ml}^{-1}$.

The amount of ascorbic acid (AsA) was determined from $0.25 \mathrm{~g}$ of fresh tissues that were crushed in $10 \mathrm{ml}$ of $6 \%$ TCA (29). The homogenised mixture was centrifuged for $10 \mathrm{~min}$ at $4^{\circ} \mathrm{C}$ at 1000 rpm followed by the addition of $0.5 \mathrm{ml}$ of $2 \%$ dinitrophenyl hydrazine solution. A drop of thiourea solution (10\% thiourea in $70 \%$ ethanol) was added to the mixture and boiled for $20 \mathrm{~min}$. The resultant mixture was placed on ice to decrease the temperature to $25{ }^{\circ} \mathrm{C}$ followed by the addition of $5 \mathrm{ml}$ of $80 \%$ sulphuric acid (v/v) under cold conditions. The absorbance was measured at $530 \mathrm{~nm}$, and AsA content was estimated by comparing it with the standard curve prepared by a known standard of ascorbic acid. Phenols and flavonoid estimation was done on fresh plant tissue in which tissues were collected and dried at $25{ }^{\circ} \mathrm{C}$ in the dark. The dried tissues were grounded into fine powder. Out of this powdered tissue, $0.1 \mathrm{~g}$ was extracted in $10 \mathrm{ml}$ methanol by shaking it overnight at room temperature, followed by sonication for $30 \mathrm{~min}$. The resultant mixture was filtered, and filtrate was used for phenol and flavonoid estimation. Flavonoid was estimated on 500 
$\mu \mathrm{l}$ of methanol extract in which $0.5 \mathrm{ml}$ of $2 \%$ aluminium chloride solution was added in methanol (30). Incubation was done at room temperature for 60 min and absorbance was measured at $240 \mathrm{~nm}$. The resulting yellow colour intensity indicated the presence of flavonoids. Standard curve plotted for solution of quercetin at varying concentrations $(10,20$, 40, 80 and $160 \mathrm{~g} \mathrm{ml}^{-1}$ ) was used for quantification and total flavonoid content was expressed as quercetin (mg g-1 dry weight).

Total phenolic content was determined by FolinCiocalteu method (31). A $1.16 \mathrm{ml}$ of distilled water and $100 \mu \mathrm{l}$ of Folin-Ciocalteu reagent were added to $20 \mu \mathrm{l}$ aliquot of methanol extract, followed by addition of $300 \mu \mathrm{l}$ of $20 \% \mathrm{Na}_{2} \mathrm{CO}_{3}$ solution. The mixture was kept in a shaking incubator at $40{ }^{\circ} \mathrm{C}$ for $30 \mathrm{~min}$ and its absorbance was measured at $760 \mathrm{~nm}$. Gallic acid was used as a standard for the preparation calibration curve. Total phenolic contents were expressed as gallic acid (mg g ${ }^{-1}$ dry weight).

\section{Statistical analysis}

All experiments were performed in triplicate $(n=3)$ and were expressed as average \pm standard deviation. The data was analysed using two-way analysis of variance (ANOVA), with inoculation treatment (with and without AM) and water level as source of variation. Duncan's multiple range test (DMRT) was performed by SPSS software (32) for comparative analysis under all water levels in all treatments.

\section{Results}

\section{Effect of AM inoculation on morphological parameters and phosphorous uptake}

To evaluate the response of finger millet seedlings to drought, the seedlings were subjected to well-watered (100\% FC), mild stress (60\% FC) and severe stress (40 $\% \mathrm{FC}$ ) condition for 10 days. It was found that length, fresh weight, and dry weight of shoot and root were reduced under soil moisture depletion under mycorrhized and non-mycorrhized conditions (Fig. 1). However, compared to the non-mycorrhized seedlings, the reduction rate of morphological characters was negligible in mycorrhiza inoculated seedlings. Seedling's height was also more in the case of AM inoculated plants i.e., 44, 40 and $38 \mathrm{~cm}(18,11$ and $7 \%$ more than non-inoculated seedlings) (Table 1). Mycorrhiza treated seedlings showed maximum increase in the fresh weight of shoot and root at $60 \%$ FC (mild stress) i.e., 54.46 and $62 \%$, respectively compared to the control. Number of leaves was more in the cases of treated plants and highest percent increase was also observed under mild stress i.e., $33 \%$ more than control. Mycorrhizal colonization had significant effect on the root length under severe drought stress, that showed $15 \%$ more root length compared to the non-mycorrhizal seedlings. Highest increase in shoot dry mass was observed under severe stress ( $40 \%$ FC), and it was found to be $70 \%$ more compared to the control seedlings (Table 1). The results indicated that mycorrhiza inoculum has improved the biomass, especially the root biomass under water stress. To analyse the representative nutrient status of the seedlings, the phosphorous content was estimated; and found that it was significantly higher in AM seedlings. The highest percent increase (44\%) was observed at $40 \%$ FC $(2.27$ $\mathrm{mg} \mathrm{g}^{-1}$ tissue) as compared to the control (1.57 $\mathrm{mg} \mathrm{g}^{-1}$ tissue) (Table 1).

\section{Mycorrhiza colonization of roots under water stress}

In the present study, no colonization by mycorrhiza was observed in non-inoculated seedlings. In the inoculated seedlings, it was decreased with the aggravation of drought stress, and was 54, 48 and $25 \%$ under well-watered, mild stress and severe stress, respectively (Table 1).

\section{Chlorophyll content in seedlings under stress}

AM inoculation was significantly increased the total chlorophyll content, even in drought stress. In AMinoculated seedlings it was significantly more than uninoculated seedlings, and highest increase observed at $100 \% \mathrm{FC}$ was $43 \%\left(0.56 \mathrm{mg} \mathrm{g}^{-1} \mathrm{FW}\right)$. During the severe stress at $40 \% \mathrm{FC}$, the total chlorophyll in AMinoculated seedlings was $29 \%\left(0.31 \mathrm{mg} \mathrm{g}^{-1} \mathrm{FW}\right)$ more than control (Fig. 2).

\section{Effect of drought on biochemical parameters of finger millet}

\section{Proline content}

Because of the drought treatment, proline content was found to be more in leaves of AM treated finger millet compared to the non-inoculated seedlings (Fig. 3A). No significant differences were observed between AMinoculated and control seedlings under well-watered condition. But under severe stress condition, proline content was $27 \mu \mathrm{g} \mathrm{g}^{-1}$ of fresh weight in AM inoculated seedlings i.e., $13.71 \%$ higher than control $\left(24.14 \mu \mathrm{g} \mathrm{g}^{-1}\right.$ FW). We also found that root accumulated higher proline content compared to the leaves. In AM treated seedlings, proline content was significantly upregulated under moderate and severe drought stresses, and highest concentration was found at $40 \%$ FC i.e., $63.57 \mu \mathrm{g} \mathrm{g}^{-1}$ of FW of root, whereas $33.55 \mu \mathrm{g} \mathrm{g}^{-1}$ of FW in control (89.4 \% more than control) (Fig. 3B).

\section{Total soluble sugars (TSS) content}

Our results indicated an increase in TSS content with the reduction in soil moisture in both the treatments (Fig. 3C, 3D). Soluble sugar level in leaves was more in AM-inoculated seedlings under both stresses, and higher content of TSS osmolyte was found in AM seedlings (173.73 $\mathrm{mg} \mathrm{g}^{-1} \mathrm{FW}$ ). The TSS osmolyte content in non-AM plants was found to be $158.93 \mathrm{mg} \mathrm{g}^{-1} \mathrm{FW}$ under severe stress $\left(\begin{array}{llll}40 & \% & F C\end{array}\right)$. Soluble sugar concentration in the roots of AM seedlings was increased significantly under 60 and $40 \%$ FC, which was $53 \%\left(90.82 \mathrm{mg} \mathrm{g}^{-1}\right.$ of FW) and $34 \%\left(93.37 \mathrm{mg} \mathrm{g}^{-1}\right.$ of FW) higher compared to the control $\left(59.19 \mathrm{mg} \mathrm{g}^{-1}\right.$ of FW and $90.82 \mathrm{mg} \mathrm{g}^{-1}$ of FW) (Fig. 3D).

\section{Malondialdehyde (MDA) content}

To analyse lipid peroxidation, the MDA content was measured. In leaves, the inoculation of AM fungus was more persistent in improving plant membrane stability by decreasing the level of MDA in finger millet under drought stress. Under severe stress condition, MDA content in leaves of AM treated 
seedlings was found to be less (44.66 nM g-1 FW) than non-AM (54 $\mathrm{nM} \mathrm{g}^{-1}$ of FW), that indicated the presence of less oxidative damage due to the AM treatment. It showed a $22 \%$ decrease of MDA in non-AM seedings (Fig. 3E). In the cases of roots, MDA accumulation was higher as compared to the leaf tissues. Higher MDA content was observed under $60 \%$ and $40 \%$ FC, and that was $18 \%$ and $28 \%$ more in non-AM plants compared to the mycorrhizal roots (Fig. 3F). These findings indicated that higher degree of oxidative stress was observed in control plants and mycorrhiza helps in mitigating oxidative damage.

\section{Hydrogen peroxide $\left(\mathrm{H}_{2} \mathrm{O}_{2}\right)$ content}

The $\mathrm{H}_{2} \mathrm{O}_{2}$ content in finger millet tissues was increased in all the stress treatments, but we found that, in all the AM inoculated seedlings $\mathrm{H}_{2} \mathrm{O}_{2}$ level was decreased significantly compared to the control. Highest $\mathrm{H}_{2} \mathrm{O}_{2}$ content $\left(0.59 \mu \mathrm{M} \mathrm{g}^{-1}\right.$ of $\left.\mathrm{FW}\right)$ was observed in non-AM plants under severe stress (40\% FC), whereas in AM

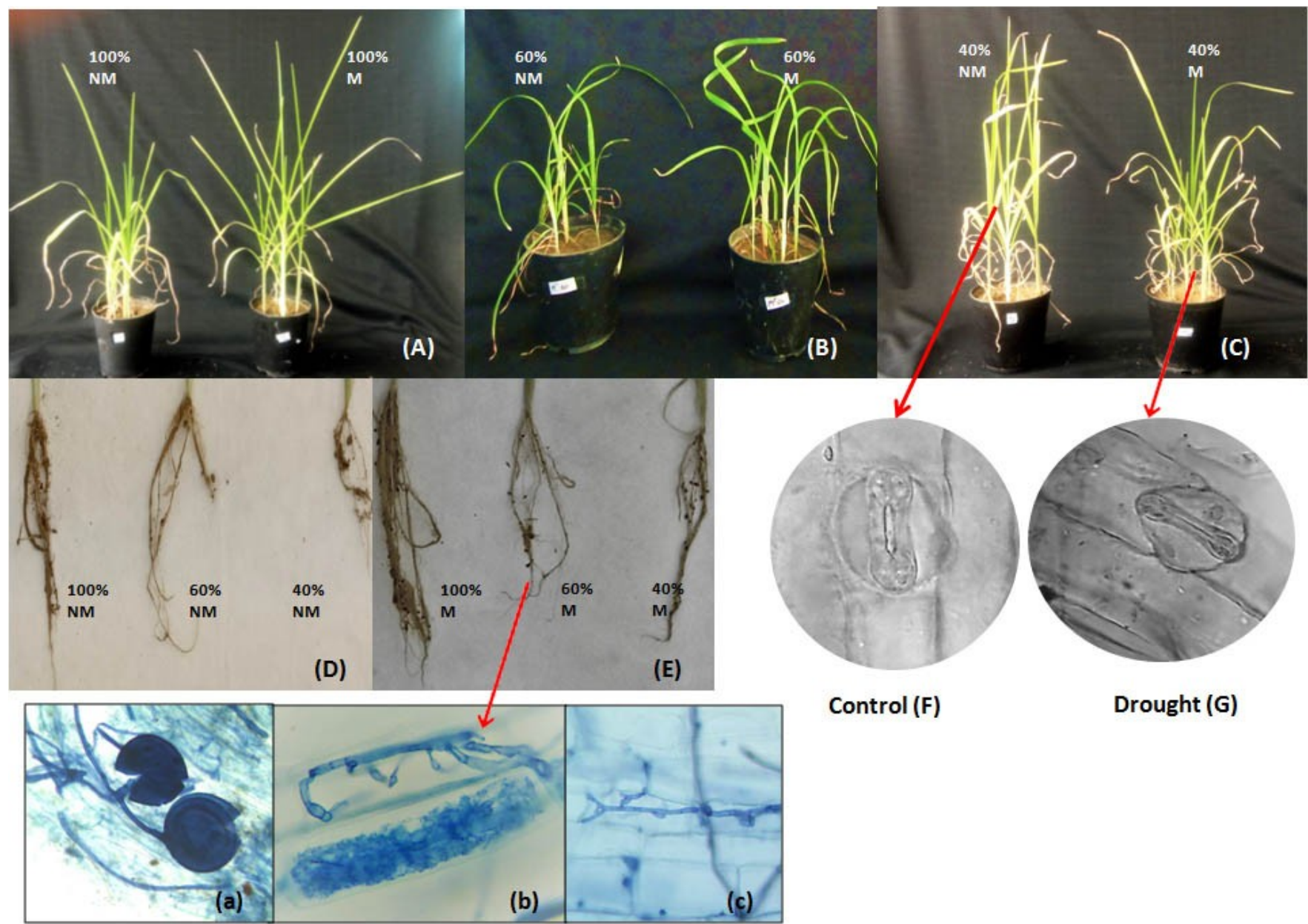

(H)

Fig. 1. Effect of mycorrhiza on plant growth at 100\% field capacity (A), $60 \%$ field capacity (B), and $40 \%$ field capacity (C); effect of different field capacity on root length of control (NM) plant (D) and root length of mycorrhizal (M) plants (E); microscopic images of stomata from leaves of finger millet control leaves in which stomata are open (F); closed stomata in leaves exposed to drought stress (G); trypan blue stained finger millet plant roots (a) spores; (b) arbuscules; and (c) intraradical hyphae (H).

Table 1. Effect of mycorrhiza on finger millet plant characteristics - shoot and root length, shoot and root fresh weight, shoot and root dry weight, number of leaves per plant, root colonization percentage (\%) and phosphorus content, under different moisture regimes.

Values are the means of three replications \pm SD and same letters indicate that means are not significantly different (P < 0.05). NM: noninoculated control and M: inoculated with mycorrhiza, FC: Field capacity, WW: well-watered, MS: mild-stress, and SS: severe-stress

\begin{tabular}{|c|c|c|c|c|c|c|c|c|c|c|}
\hline $\begin{array}{c}\text { Drought } \\
\text { Treatment }\end{array}$ & $\begin{array}{c}\text { Fungal } \\
\text { Inoculants }\end{array}$ & $\begin{array}{c}\text { Shoot } \\
\text { length } \\
\text { (cm) }\end{array}$ & $\begin{array}{c}\text { Root } \\
\text { length } \\
\text { (cm) }\end{array}$ & $\begin{array}{c}\text { Shoot fresh } \\
\text { weight } \\
\text { (gm) }\end{array}$ & $\begin{array}{l}\begin{array}{l}\text { Shoot dry } \\
\text { weight } \\
\text { (gm) }\end{array} \\
\end{array}$ & $\begin{array}{l}\text { Root fresh } \\
\text { weight } \\
\text { (gm) }\end{array}$ & $\begin{array}{c}\text { Root dry } \\
\text { weight } \\
\text { (gm) }\end{array}$ & $\begin{array}{c}\text { No. of } \\
\text { Leaves/ } \\
\text { Plant }\end{array}$ & $\begin{array}{c}\text { Phosphorus } \\
\text { content } \\
\text { (mg/g tissue) }\end{array}$ & $\begin{array}{c}\text { Mycorrhizal } \\
\text { Colonization } \\
(\%)\end{array}$ \\
\hline \multirow{2}{*}{$\begin{array}{c}100 \% \text { FC } \\
\text { (WW) }\end{array}$} & NM & $\begin{array}{c}37.6 \pm \\
0.36 \mathrm{a}, \mathrm{b}\end{array}$ & $17.9 \pm 0.56 c$ & c $1.98 \pm 0.11 b$ & $\begin{array}{l}0.20 \pm \\
0.03 \mathrm{~b}\end{array}$ & $\begin{array}{l}0.18 \pm \\
0.02 \mathrm{~b}\end{array}$ & $0.036 \pm 0.02 \mathrm{~b}, \mathrm{c}$ & $\begin{array}{c}7.3 \pm \\
0.57 \mathrm{~b}, \mathrm{c}\end{array}$ & $\begin{array}{l}3.66 \pm \\
0.14 \mathrm{c}\end{array}$ & $\begin{array}{l}0.00 \pm \\
0.0 \mathrm{a}\end{array}$ \\
\hline & M & $\begin{array}{l}44.7 \pm \\
2.08 \mathrm{~d}\end{array}$ & $\begin{array}{l}20.6 \pm \\
1.21 \mathrm{~d}\end{array}$ & $\begin{array}{l}2.76 \pm \\
0.18 \mathrm{c}\end{array}$ & $\begin{array}{l}0.29 \pm \\
0.01 \mathrm{c}\end{array}$ & $\begin{array}{l}0.28 \pm \\
0.02 \mathrm{c}\end{array}$ & $\begin{array}{l}0.049 \pm \\
0.003 c\end{array}$ & $9.3 \pm 0.57 d$ & $\begin{array}{l}4.29 \pm \\
0.44 \mathrm{~d}\end{array}$ & $\begin{array}{l}54.0 \pm \\
5.29 \mathrm{c}\end{array}$ \\
\hline $\begin{array}{c}60 \% \text { FC } \\
\text { (MS) }\end{array}$ & NM & $\begin{array}{c}36.4 \pm \\
0.81 \mathrm{a}, \mathrm{b} \\
\end{array}$ & $\begin{array}{l}14.8 \pm \\
0.47 \mathrm{~b}\end{array}$ & $\begin{array}{l}1.12 \pm \\
0.13 a\end{array}$ & $\begin{array}{l}0.17 \pm \\
0.03 \mathrm{~b} \\
\end{array}$ & $\begin{array}{l}0.16 \pm \\
0.01 \mathrm{~b} \\
\end{array}$ & $\begin{array}{r}0.028 \pm \\
0.004 a, b \\
\end{array}$ & $\begin{array}{c}6.3 \pm \\
0.57 \mathrm{a}, \mathrm{b} \\
\end{array}$ & $\begin{array}{l}3.43 \pm \\
0.20 \mathrm{c}\end{array}$ & $\begin{array}{c}0.00 \pm \\
0.0 \mathrm{a} \\
\end{array}$ \\
\hline \multirow{2}{*}{$\begin{array}{c}40 \% \text { FC } \\
\text { (SS) }\end{array}$} & NM & $\begin{array}{l}36.0 \pm \\
1.25 \mathrm{a} \\
\end{array}$ & $\begin{array}{l}12.1 \pm \\
0.66 \mathrm{a}\end{array}$ & $\begin{array}{l}0.90 \pm \\
0.24 \mathrm{a}\end{array}$ & $\begin{array}{l}0.10 \pm \\
0.02 \mathrm{a}\end{array}$ & $\begin{array}{l}0.13 \pm \\
0.02 \mathrm{a}\end{array}$ & $\begin{array}{l}0.015 \pm \\
0.002 \mathrm{a}\end{array}$ & $5.3 \pm 0.57 a$ & $\begin{array}{l}1.57 \pm \\
0.29 a \\
\end{array}$ & $\begin{array}{l}0.00 \pm \\
0.0 \mathrm{a} \\
\end{array}$ \\
\hline & M & $\begin{array}{c}38.7 \pm \\
0.87 \mathrm{~b}, \mathrm{c}\end{array}$ & $\begin{array}{r}14.0 \pm \\
1.70 \mathrm{a}, \mathrm{b} \\
\end{array}$ & $\begin{array}{l}1.15 \pm \\
0.13 \mathrm{a} \\
\end{array}$ & $\begin{array}{l}0.17 \pm \\
0.03 \mathrm{~b} \\
\end{array}$ & $\begin{array}{l}0.17 \pm \\
0.02 \mathrm{~b} \\
\end{array}$ & $\begin{array}{r}0.018 \pm \\
0.003 a, b \\
\end{array}$ & $6.6 \pm 0.57 b$ & $\begin{array}{l}2.27 \pm \\
0.24 \mathrm{~b} \\
\end{array}$ & $\begin{array}{l}25.3 \pm \\
4.93 \mathrm{~b} \\
\end{array}$ \\
\hline
\end{tabular}




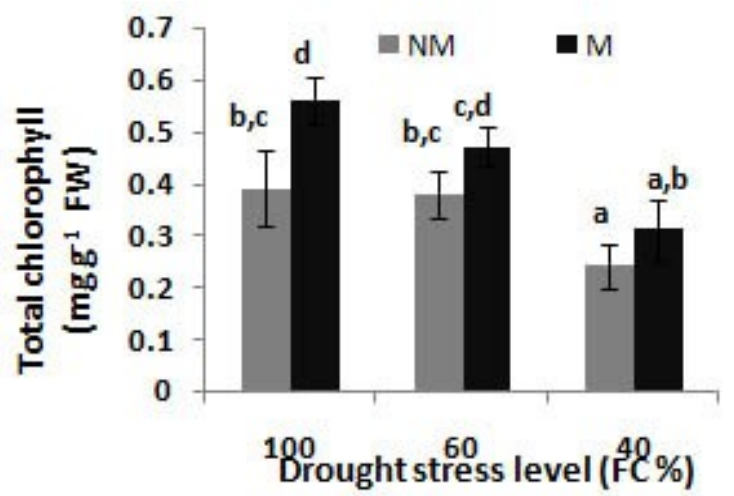

Fig. 2. Effect of different soil water levels ( $100 \%, 60 \%$, and $40 \%$ FC) and AM colonization on chlorophyll content in finger millet leaves. Values are the means of three replications \pm SD. Mean with same letter are not significantly different $(\mathrm{P}<0.05)$. Control (non-mycorrhizal NM) and treated (mycorrhizal M), FC: Field capacity, WW: well-watered, MS: mild-stress and SS: severe-stress.

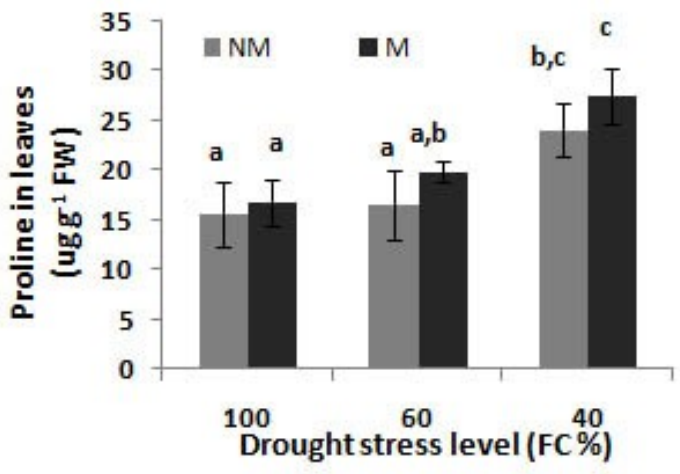

(A)

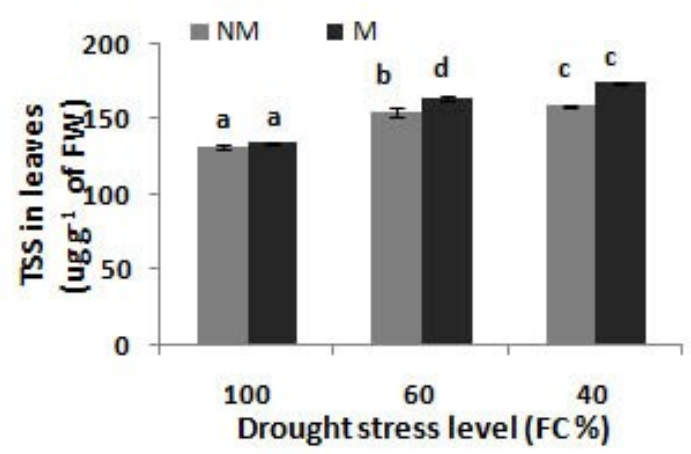

(C)

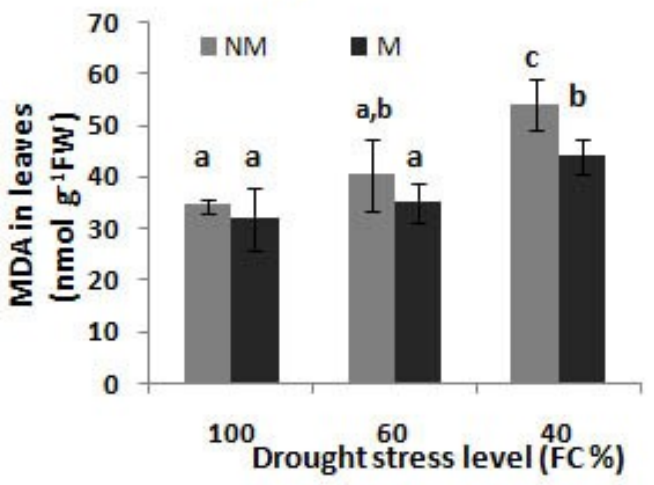

(E)

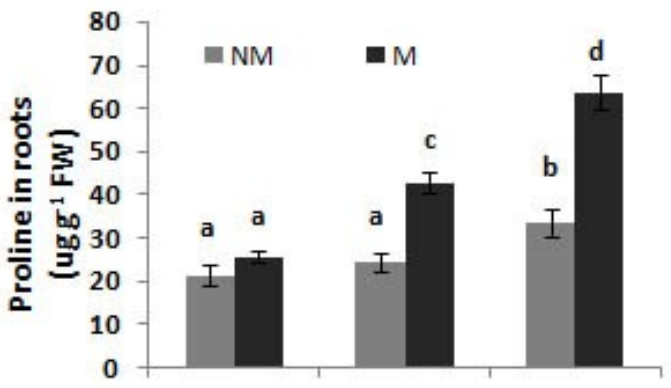

Biought stres5 level (FC\%)

(B)

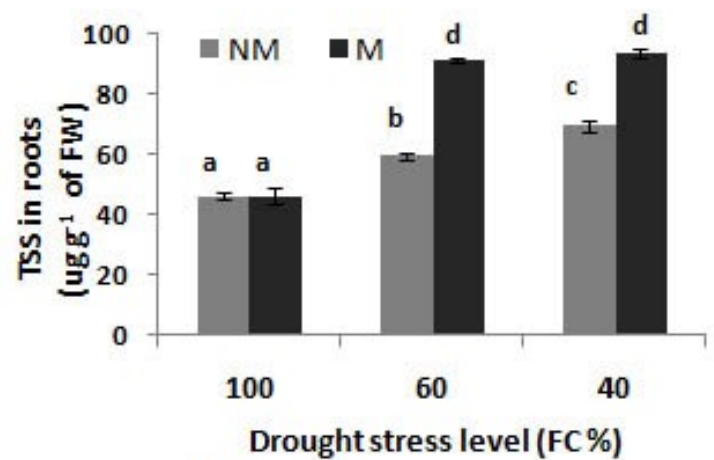

(D)

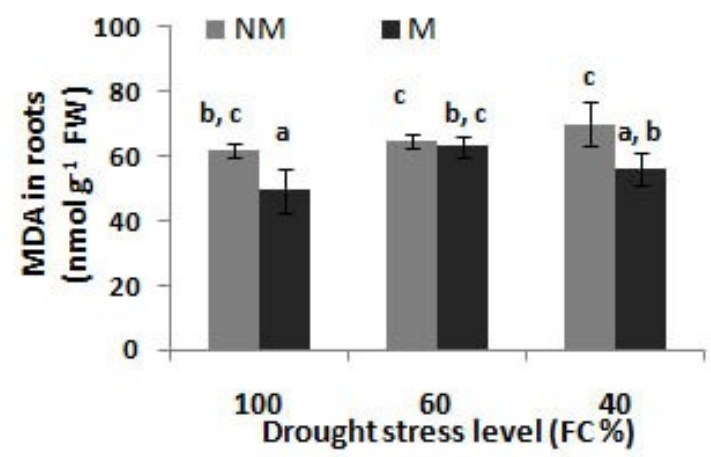

(F)

Fig. 3. Effect of water stress and AM on proline content in leaves (A) and roots (B), Total soluble sugars (TSS) leaves (C) and roots (D), Malondialdehyde (MDA) content in leaves (E) and root (F) in Finger millet seedlings. Values are the means of three replications \pm SD. Mean with same letter are not significantly different $(\mathrm{P}<0.05)$. Control (non-mycorrhizal NM) and treated (mycorrhizal M), FC: Field capacity, WW: well-watered, MS: mild-stress and SS: severe-stress. 


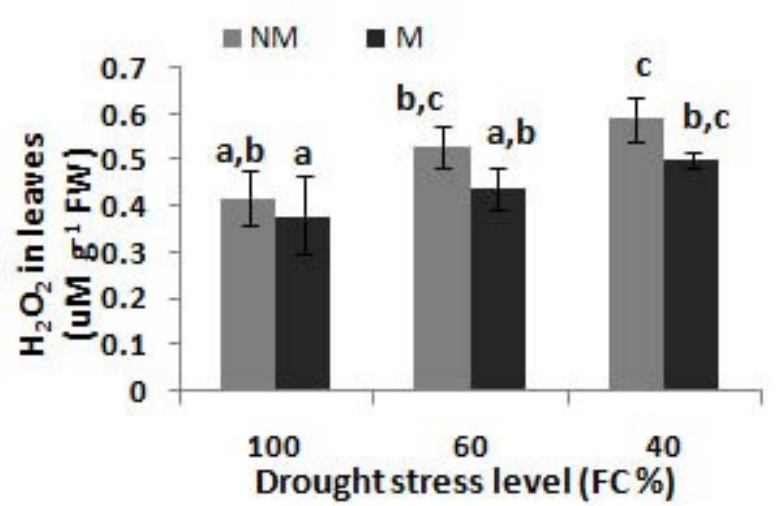

(A)

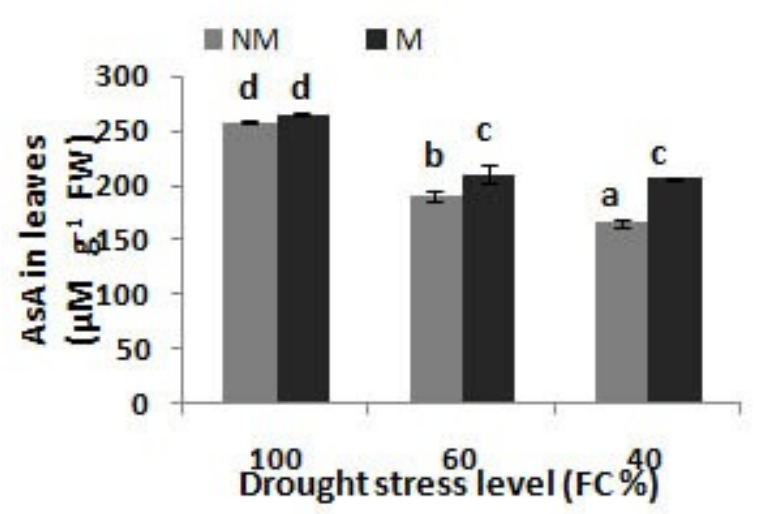

(C)

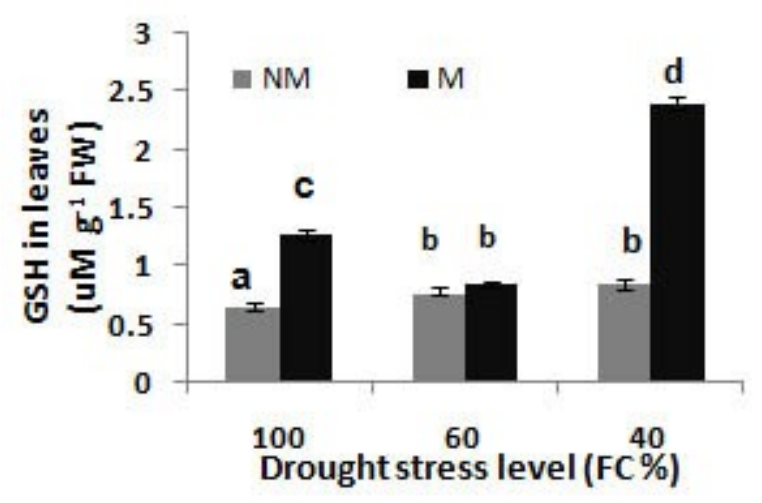

(E)

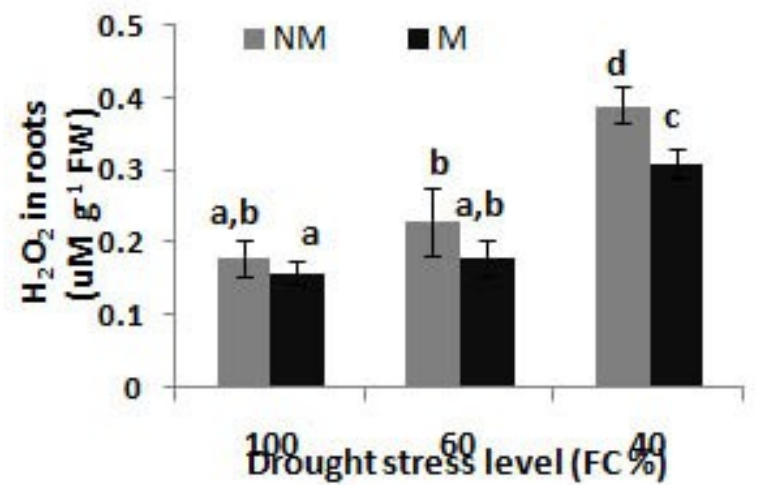

(B)

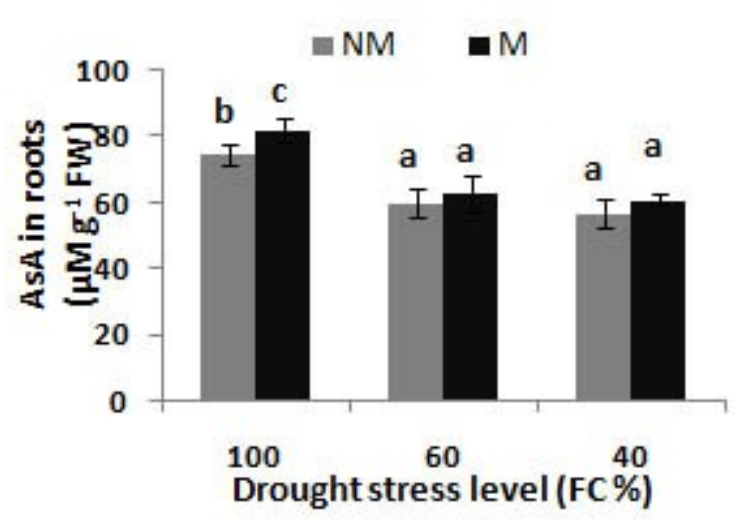

(D)

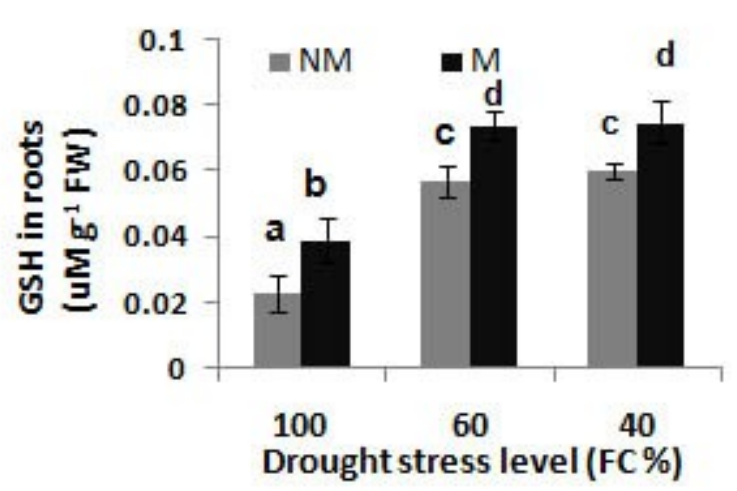

(F)

Fig. 4. Effect of drought stress on hydrogen peroxide $\left(\mathrm{H}_{2} \mathrm{O}_{2}\right)$ content leaves (A) and roots (B), ascorbate-glutathione status in leaves (C) (E) and roots (D) (F) at different moisture levels $(100 \%, 60 \%$, and $40 \%$ field capacity (FC). Values are the means of three replications \pm SD. Mean with same letter are not significantly different ( $<0.05)$. Control (non-mycorrhizal NM) and treated (mycorrhizal M), FC: Field capacity, WW: well-watered, MS: mild-stress and SS: severe-stress.

treated plants it was found to be $0.50 \mu \mathrm{M} \mathrm{g} \mathrm{g}^{-1}$ of $\mathrm{FW}$ (Fig. 4A). In the case of roots, the level of $\mathrm{H}_{2} \mathrm{O}_{2}$ followed the same trend of leaves, where AM inoculation showed its significant effect under both stress levels. Higher variation among the control and treated roots was seen at $40 \% \mathrm{FC}$, where AM- seedlings showed $16 \%$ less $\mathrm{H}_{2} \mathrm{O}_{2}$ accumulation than control (Fig. 4B).

\section{Ascorbate (AsA) and Glutathione (GSH) content}

In the present study, ascorbate content (AsA) was found to be decreased with the increase in level of water stress, and AM inoculated plants had showed higher ascorbate content than control under all stress levels. In well-watered conditions, the differences in both non-mycorrhized and mycorrhized seedlings were non-significant, indicating nearly same ascorbate redox status (Fig. 4C). With the depletion of water content, AM fungus was more able to improve the ascorbate showed a significant increase of $10 \%$ to $25 \%$ under $60 \%$ and $40 \%$ FC, respectively. Roots accumulated less ascorbate content compared to the leaf tissue and no significant changes were observed under mild and severe stress (Fig. 4D).

We also found that, GSH was highly affected by AM fungi; specially in the case of leaf tissue. It was increased in all drought stress treatments, but higher variation was found at $40 \%$ FC with a significant 
increase of $182 \%$ in AM inoculation $\left(2.4 \mu \mathrm{M} \mathrm{g}^{-1} \mathrm{FW}\right)$ compared to control seedlings $\left(0.85 \mu \mathrm{M} \mathrm{g}^{-1} \mathrm{FW}\right)$ (Fig. $4 \mathrm{E})$. Root accumulates significantly less amount of glutathione compared to the leaves, while the results were significant and in favour with the AM seedlings (Fig. 4F).

\section{Phenol and flavonoid content}

Total phenolic and flavonoid content were also assayed to understand the influence of water stress on secondary metabolites in finger millet seedlings. With the induced water stress, phenol level was increased in all the treatments (Fig. 5A). No significant change was observed at $100 \%$ FC, but AM showed its significant influence on phenol accumulation in roots under mild stress (139 mg gallic acid $\mathrm{g}^{-1}$ of $\left.\mathrm{DW}\right)$, which was $13 \%$ more as

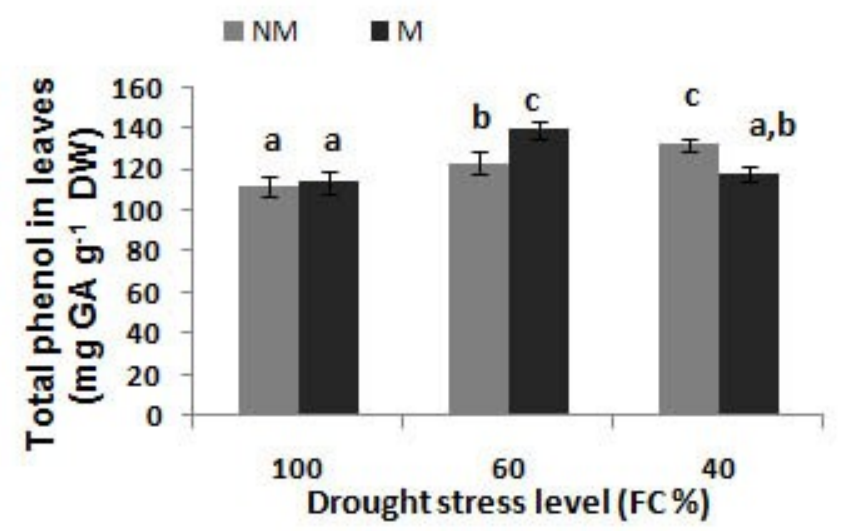

(A)

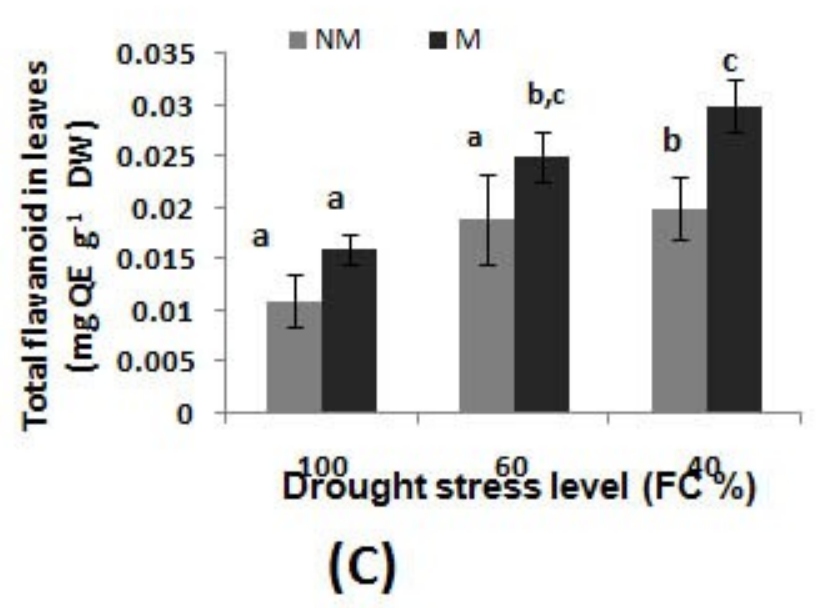

Total flavonoid content in the leaves and roots was also increased in both treatments with the reduction in soil moisture level. No significant difference was observed under well-watered condition, but in the leaves of mycorrhizal treated seedlings, there was a $30 \%\left(0.025 \mathrm{mg} \mathrm{g}^{-1}\right.$ of DW) and $50 \%\left(0.030 \mathrm{mg} \mathrm{g}^{-1}\right.$ of DW) increase in flavonoid content compared to non-AM plant under mild $(0.015$ $\mathrm{mg} \mathrm{g}^{-1}$ of DW) and severe stress (0.022 $\mathrm{mg} \mathrm{g}^{-1}$ of DW) (Fig. 5C). Results also showed that finger millet roots accumulated more flavonoid than leaves (Fig. 5D). At $60 \% \mathrm{FC}$, flavonoid content in the AM-inoculated roots was nearly same as compared to the control, but under severe stress condition mycorrhiza showed a significant effect with $16.48 \%$ increase compared to the control.

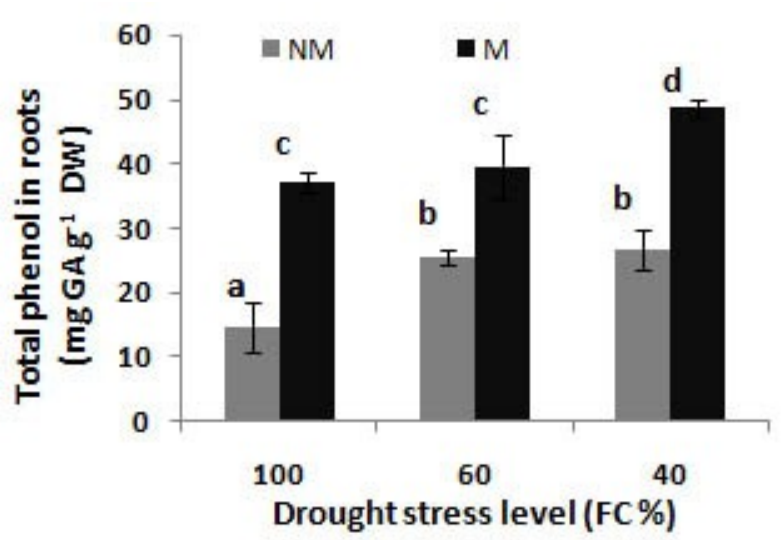

(B)

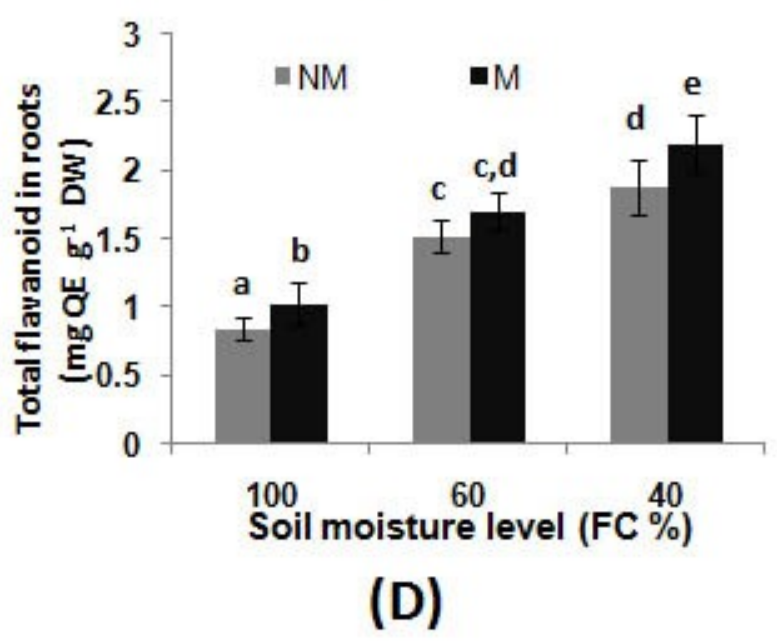

Fig. 5. Effect of drought stress on antioxidant metabolites in finger millet total phenol in leaves (A) and roots (B), Total flavonoid in leaves (C) and roots (D) with and without AM inoculation. Values are the means of three replications \pm SD. Mean with same letter are not significantly different $(\mathrm{P}<0.05)$. FC: Field capacity, WW: well-watered, MS: mild-stress, and SS: severe-stress.

compared to the non-AM seedlings. In the case of leaves under severe stress condition, mycorrhiza treatment was not effective in respect of increase in phenol content. Roots accumulated less phenol than leaf tissues; significant and high variation could be seen between roots of treated and control seedlings. High phenol content was observed in AM-inoculated roots under mild and severe stress $\left(39.64 \mathrm{mg} \mathrm{g}^{-1}\right.$ of DW and $48.66 \mathrm{mg} \mathrm{g}^{-1}$ of $\mathrm{DW}$, respectively). The increase was $35 \%$ and $46 \%$ more compared to the control (Fig. 5B).

\section{Discussion}

Seedling stage is more sensitive to the drought stress than the subsequent ones. It severely limits the crop stand and subsequent yield of various crop plants. The aim of the present study was to evaluate the effect of mycorrhizal symbiosis during water stress on growth of finger millet seedlings. Avoidance and tolerance are the two main strategies through which mycorrhized plants cope up with abiotic stress (11). Extensive hyphal network makes it perfect drought avoider by maintaining an adequate hydration status inside the 
plant cell and promote the plant growth through enhanced absorption of nutrient's from the soil (10). Along with this, the effect of AM on the stress tolerance has often been measured in terms of osmolyte, secondary metabolite accumulation and biomass production (33). Plant growth promoting rhizobacteria (PGPR) improved the plant growth and nutrient status under stress condition by inducing systemic resistance, secreting various signalling hormones, stress responsive genes and volatile compounds (34). Recently, under drought stress the plant growth promoting effect of bacterial consortium (Variovorax sp., Achromobacter spp., Pseudomonas spp., and Ochrobactrum spp.) has been reported. The single inoculant of RAA3 (Variovorax paradoxus) and a consortium inoculant of four bacteria, i.e., DPC9 (Ochrobactrum anthropi), DPB13 (Pseudomonas palleroniana), DPB15 (Pseudomonas fuorescens) and DPB16 (Pseudomonas palleroniana) has been reported useful in finger millet under drought stress (35).

In the present study, AM symbiosis enhanced the growth and biomass of finger millet seedlings under water stress. Drought stress has reduced the shoot and root biomass of finger millet seedlings (both AM and non-AM seedlings). However, the length, fresh and dry weights of the roots and shoots in AM seedlings were found to be more under mild and severe drought stress. Similar results were previously reported in Pistacia vera L. (36) and Zea mays (37) where AM fungi had enhanced the tolerance potential to the abiotic stresses by improving the physiological parameters. Drought affects plant chlorophyll content, indicating a lower photosynthetic capacity. But chlorophyll content in AM treated finger millet seedlings was more by $23.68 \%$ and $29.16 \%$ under mild and severe stress condition, respectively. This indicated that lessor damage to photosynthetic ability of finger millet was might be due to greater availability of nutrient and water content from the soil through AM symbiosis. Similar results were also reported in other crops under severe drought stress $(38,39)$. We found enhanced accumulation of phosphorous in mycorrhizal seedlings under well-watered and severe stress conditions, and similar finding was previously observed in many other plant species (40).

Drought stress in finger millet seedlings significantly affected the mycorrhizal colonization. Similar results have been reported in Helianthemum almeriense and Terfezia claveryi orchards (41). The results have confirmed the hypothesis that after establishment of initial symbiosis of AM with plant, water stress reduces the AM growth in the soil by inhibiting the spore germination and spread of extra radical mycelium (ERM) through branching (42). The lesser the photosynthetic efficiency in the host plant induced by drought stress, lesser the quantity of root carbohydrates, and hence the rate of AM colonization $(43,44)$.

Proline has been broadly considered as a drought-inducible metabolite with an osmoprotective role. It has been reported that, accumulation and interaction of proline and soluble sugars preserved a high antioxidant protection in leaves of Arabidopsis thaliana under drought stress (45). As expected, we also found high proline content under drought stress.
The higher proline accumulation in AM treated finger millet root and leaf was more than that of non-AM plant under severe stress and was in agreement with the previous findings (17). It was also found that leaves have lower proline content as compare to roots, which might be probably because, its synthesis occur in the shoots and then transported to the roots to maintain the growth at low water level (46).

Along with proline, soluble sugars also play an important role in protecting membrane integrity through osmotic adjustment (5). In our study, drought was found to increase the accumulation of soluble sugars more in the presence of AM compared to the control. Leaves in AM treated seedlings were accumulated more carbohydrate than roots and may be an outcome of the enhanced photosynthetic efficiency and the sink effect of fungal demand for sugars from leaves to roots $(47,48)$.

It has been concluded that AM inoculation resulted in reduced the lipid peroxidation and hydrogen peroxide concentration in seedlings under the drought stress. In roots, higher lipid peroxidation was observed under severe stress and less MDA was accumulated in AM treated roots. Most of the studies have demonstrated that lipid peroxidation is a biomechanism of cellular damage in living organisms and can be used as an indicator of oxidative stress. The increase of MDA content in the leaves indicates that the bulk oxidative lipid synthesis was induced by drought, suggesting a close relationship between drought and oxidative stress $(49,50)$.

Interestingly, ascorbate protects the plant cell against oxidative damage by its ability to function as an electron donor in a broad range of enzymatic and non-enzymatic reactions (51). Both AsA and GSH participate in the AsA-GSH cycle and helps to neutralise $\mathrm{H}_{2} \mathrm{O}_{2}$ into water and oxygen (52). The $\mathrm{H}_{2} \mathrm{O}_{2}$ content was increased with drought in control seedlings, but in treated plants it was significantly reduced. The $\mathrm{H}_{2} \mathrm{O}_{2}$ content was highly affected at mild stress that shows $44 \%$ less $\mathrm{H}_{2} \mathrm{O}_{2}$ content in $\mathrm{AM}$ seedlings than control. It was reported that $\mathrm{AM}$ symbiosis improve the response of plants to drought largely through the accumulation of the antioxidant compound like glutathione. The glutathione was found to be associated with a reduction in oxidative damage to membrane lipids and cellular $\mathrm{H}_{2} \mathrm{O}_{2}(11,53)$. On the other hand, ascorbate levels were less in the mycorrhizal plants compared to the non-mycorrhizal counterparts. Similar findings were found in the present study as well, where the leaves of AM inoculated finger millet had increased glutathione level in severe drought stress, and ascorbate levels were decreased in the mycorrhizal plants. This is in accordance with the previous reports in rice where antioxidant compound glutathione was higher in AM plants compared to the non-AM (54).

In our study, phenols and flavonoids content in finger millet leaves were increased during drought stress. High content of phenol and flavonoid was also observed in AM treated seedlings. Recent studies have shown that accumulation of phenols, flavonoids can significantly increase in the plants under mild drought stress (55). As ROS is highly responsible for oxidative 
burst in plant cell, prevention of ROS production is achieved by compounds such as phenolic, flavonoids and antioxidants. The drought stress led to enhancement of these metabolites in the seedlings.

\section{Conclusion}

It has been concluded from the results that AM fungi symbiosis with the finger millet seedlings has improved the plant growth performance under drought stress. The beneficial effect of the AM symbiosis was linked to the effective osmotic adjustment mechanism by accumulation of proline and soluble sugars; along with soluble phenols and AsA-GSH cycle. The drought stress decreased the shoot and root yield, but enhanced the accumulation of phosphorus and water, which could help seedlings to cope up with the water stress conditions. Thus, the arbuscular mycorrhizal fungi Rhizophagus intraradices can be an efficient plant growth promoting fungi to enhance drought tolerance in finger millet seedlings. Further research on the molecular aspects of this AM assisted drought tolerance can reveal more to understand the molecular basis of drought tolerance.

\section{Acknowledgements}

Authors gratefully acknowledge the funding to RNP under TARE fellowship by Science and Engineering Research Board, Department of Science and Technology (TAR/2020/000166).

\section{Authors' contributions}

JT performed the experiments, NSAKS, AV performed data analysis and paper drafting, and RNP designed the experiments, supervised the work and finalized the manuscript. All the authors have read the manuscript and provided comments.

\section{Compliance with ethical standards}

\section{Conflict of interest}

The authors declare that they have no conflicts of interest.

\section{Ethical issues}

None.

\section{References}

1. Upadhyaya HD, Ramesh S, Sharma S, Singh SK, Varshney SK, Sarma ND, Ravishankar CR, Narasimhudu Y, Reddy VG, Sahrawat KL, Dhanalakshmi TN. Genetic diversity for grain nutrients contents in a core collection of finger millet (Eleusine coracana (L.) Gaertn.) germplasm. Field Crops Research. 2011;121(1):42-52. https://doi.org/10.1016/ j.fcr.2010.11.017

2. Kumar A, Gaur VS, Goel A, Gupta AK. De novo assembly and characterization of developing spikes transcriptome of finger millet (Eleusine coracana): a minor crop having nutraceutical properties. Plant Molecular Biology Reporter. 2015;33(4):905-22. https://doi.org/10.1007/s11105-014-0802-5
3. Rosegrant MW, Cai X, Cline SA. World water and food to 2025: dealing with scarcity. Intl Food Policy Res Inst. 2002.

4. Kurepin LV, Ivanov AG, Zaman M, Pharis RP, Hurry V, Hüner NP. Interaction of glycine betaine and plant hormones: protection of the photosynthetic apparatus during abiotic stress. In: Photosynthesis: Structures, mechanisms and applications 2017;185-202. Springer, Cham. https://doi.org/10.1007/978-3319-48873-8_9

5. Choudhury FK, Rivero RM, Blumwald E, Mittler R. Reactive oxygen species, abiotic stress and stress combination. The Plant Journal. 2017;90(5):856-67. https://doi.org/10.1111/ tpj.13299

6. Noctor G, Mhamdi A, Foyer $\mathrm{CH}$. The roles of reactive oxygen metabolism in drought: not so cut and dried. Plant Physiology. 2014;164(4):1636-48. https://doi.org/10.1104/ pp.113.233478

7. Petrov V, Hille J, Mueller-Roeber B, Gechev TS. ROS-mediated abiotic stress-induced programmed cell death in plants. Frontiers in Plant Science. 2015;18(6):691-96. https:// doi.org/10.3389/fpls.2015.00069

8. Ma D, Sun D, Wang C, Li Y, Guo T. Expression of flavonoid biosynthesis genes and accumulation of flavonoid in wheat leaves in response to drought stress. Plant Physiology and Biochemistry. 2014;(1):80-60-66. https://doi.org/10.1016/j.plaphy.2014.03.024

9. Das K, Roychoudhury A. Reactive oxygen species (ROS) and response of antioxidants as ROS-scavengers during environmental stress in plants. Frontiers in Environmental Science. 2014;(2):531-5313. https://doi.org/10.3389/fenvs.2014.00053

10. Augé RM, Toler HD, Saxton AM. Arbuscular mycorrhizal symbiosis alters stomatal conductance of host plants more under drought than under amply watered conditions: a meta-analysis. Mycorrhiza. 2015;25(1):13-24. https://doi.org/ 10.1007/s00572-014-0585-4

11. Dastogeer KM, Wylie SJ. Plant-fungi association: role of fungal endophytes in improving plant tolerance to water stress. In: Plant-microbe interactions in agro-ecological perspectives. 2017; pp.143-159. Springer, Singapore. https:// doi.org/10.1007/978-981-10-5813-4_8

12. Miransari M. Contribution of arbuscular mycorrhizal symbiosis to plant growth under different types of soil stress. Plant Biology. 2010;12(4):563-69. https://doi.org/10.1111/j.14388677.2009.00308.x

13. Gonzalez-Dugo V, Durand JL, Gastal F. Water deficit and nitrogen nutrition of crops. A review. Agronomy for sustainable development. 2010;30(3):529-44. https://doi.org/ 10.1051/agro/2009059

14. Zou YN, Wang P, Liu CY, Ni QD, Zhang DJ, Wu QS. Mycorrhizal trifoliate orange has greater root adaptation of morphology and phytohormones in response to drought stress. Scientific Reports. 2017;7(1):1-10. https://doi.org/10.1038/ srep41134

15. Karasawa T, Takebe M. Temporal or spatial arrangements of cover crops to promote arbuscular mycorrhizal colonization and $\mathrm{P}$ uptake of upland crops grown after nonmycorrhizal crops. Plant and Soil. 2012;353(1):355-66. https://doi.org/ $10.1007 /$ s11104-011-1036-Z

16. Ramakrishnan K, Bhuvaneswari G. Effect of inoculation of am fungi and beneficial microorganisms on growth and nutrient uptake of Eleusine coracana (L.) Gaertn. (Finger millet). International Letters of Natural Sciences. 2014;8(2):5969. https://doi.org/10.18052/www.scipress.com/ILNS.13.59

17. Kamal R, Gusain Y.S, Sharma I.P, Sharma S. and Sharma A.K., 2015. Impact of arbuscular mycorrhizal fungus, Glomus intraradices, Streptomyces and Pseudomonas spp. strain on finger millet (Eleusine coracana L.) cv Korchara under water deficit condition. African Journal of Biotechnology. 2015; 14(48):3219-27. https://doi.org/10.5897/AJB2015.14479

18. Tisserant E, Malbreil M, Kuo A, Kohler A, Symeonidi A, Balestrini R, Charron P, Duensing N, dit Frey NF, GianinazziPearson V, Gilbert LB. Genome of an arbuscular mycorrhizal fungus provides insight into the oldest plant symbiosis. Pro- 
ceedings of the National Academy of Sciences. 2013; 110(50):20117-22. https://doi.org/10.1073/pnas.1313452110

19. Colman EA. A laboratory procdure for determining the field capacity of soils. Soil Science. 1947;1;63(4):277-84. https:// doi.org/10.1097/00010694-194704000-00003

20. Nouri E, Breuillin-Sessoms F, Feller U, Reinhardt D. Phosphorus and nitrogen regulate arbuscular mycorrhizal symbiosis in Petunia hybrida. PloS one. 2014;7;9(3):e90841. https://doi.org/10.1371/journal.pone.0090841

21. Giovannetti M, Mosse B. An evaluation of techniques for measuring vesicular arbuscular mycorrhizal infection in roots. New Phytologist. 1980;(84):489-500. https://doi.org/ 10.1111/j.1469-8137.1980.tb04556.x

22. Hiscox JD, Israelstam GF. A method for the extraction of chlorophyll from leaf tissue without maceration. Canadian Journal of Botany. 1979;57(12):1332-4. https://doi.org/ 10.1139/b79-163

23. Arnon DI. Copper enzymes in isolated chloroplasts. Polyphenoloxidase in Beta vulgaris. Plant physiology. 1949;24(1):1. https://doi.org/10.1104/pp.24.1.1

24. Bates LS, Waldren RP, Teare ID. Rapid determination of free proline for water-stress studies. Plant and Soil. 1973;39(1):205-7. https://doi.org/10.1007/BF00018060

25. Wang S, Zhu Y, Jiang H, Cao W. Positional differences in nitrogen and sugar concentrations of upper leaves relate to plant $\mathrm{N}$ status in rice under different $\mathrm{N}$ rates. Field Crops $\mathrm{Re}$ search. 2006;96(2-3):224-34. https://doi.org/10.1016/ j.fcr.2005.07.008

26. Li Y, Zhao H, Duan B, Korpelainen H, Li C. Effect of drought and ABA on growth, photosynthesis and antioxidant system of Cotinus coggygria seedlings under two different light conditions. Environmental and Experimental Botany. 2011; 1;71(1):107-13.

j.envexpbot.2010.11.005

27. Junglee S, Urban L, Sallanon H, Lopez-Lauri F. Optimized as say for hydrogen peroxide determination in plant tissue using potassium iodide. American Journal of Analytical Chemistry. 2014;5(11):730-36. https://doi.org/10.4236/ ajac. 2014.511081

28. Moron MS, Depierre JW, Mannervik B. Levels of glutathione, glutathione reductase and glutathione S-transferase activities in rat lung and liver. Biochimica et Biophysica Acta (BBA)-general subjects. 1979;582(1):67-78. https://doi.org/ 10.1016/0304-4165(79)90289-7

29. Mukherjee SP, Choudhuri MA. Implications of water stressinduced changes in the levels of endogenous ascorbic acid and hydrogen peroxide in Vigna seedlings. Physiologia Plantarum. 1983;58(2):166-70. https://doi.org/10.1111/j.13993054.1983.tb04162.x

30. Bettaieb I, Hamrouni-Sellami I, Bourgou S, Limam F, Mar zouk B. Drought effects on polyphenol composition and antioxidant activities in aerial parts of Salvia officinalis L. Acta Physiologiae Plantarum. 2011;33(4):1103-11. https://doi.org/ $10.1007 / \mathrm{s} 11738-010-0638-\mathrm{z}$

31. Slinkard K, Singleton VL. Total phenol analysis: automation and comparison with manual methods. American Journal of Enology and Viticulture. 1977;28(1):49-55.

32. Verma JP. Data Analysis in Management with SPSS Software. Springer Science and Business Media. 2012 Dec 13. https:// doi.org/10.1007/978-81-322-0786-3

33. Quiroga G, Erice G, Aroca R, Chaumont F, Ruiz-Lozano JM. Enhanced drought stress tolerance by the arbuscular mycorrhizal symbiosis in a drought-sensitive maize cultivar is related to a broader and differential regulation of host plant aquaporins than in a drought-tolerant cultivar. Frontiers in Plant Science. 2017;19(8):1056. https://doi.org/10.3389/ fpls.2017.01056

34. Khan N, Bano A, Ali S, Babar MA. Crosstalk amongst phytohormones from planta and PGPR under biotic and abiotic stresses. Plant Growth Regulation. 2020;90(2):189-203. https://doi.org/10.1007/s10725-020-00571-x
35. Chandra D, Srivastava R, Glick BR, Sharma AK. Rhizobacteria producing ACC deaminase mitigate water-stress response in finger millet (Eleusine coracana (L.) Gaertn.). 3 Biotech. 2020;10(2):1-5. https://doi.org/10.1007/s13205-019-2046-4

36. Abbaspour H, Saeidi-Sar S, Afshari H, Abdel-Wahhab MA Tolerance of mycorrhiza infected pistachio (Pistacia vera L.) seedling to drought stress under glasshouse conditions. Journal of Plant Physiology. 2012;1;169(7):704-49. https:// doi.org/10.1016/j.jplph.2012.01.014

37. Bárzana G, Aroca R, Bienert GP, Chaumont F, Ruiz-Lozano JM. New insights into the regulation of aquaporins by the arbuscular mycorrhizal symbiosis in maize plants under drought stress and possible implications for plant performance. Molecular Plant-Microbe Interactions. 2014;27(4):34963. https://doi.org/10.1094/MPMI-09-13-0268-R

38. Ashraf MH, Harris PJ. Photosynthesis under stressful environments: an overview. Photosynthetica. 2013;1;51(2):163-90. https://doi.org/10.1007/s11099-013-0021-6

39. Yooyongwech S, Samphumphuang T, Tisarum R, Theerawitaya C, Cha-Um S. Arbuscular mycorrhizal fungi (AMF) improved water deficit tolerance in two different sweet potato genotypes involves osmotic adjustments via soluble sugar and free proline. Scientia Horticulturae. 2016;(26)198:107-17. https://doi.org/10.1016/j.scienta.2015.11.002

40. Burghelea C, Zaharescu DG, Dontsova K, Maier R, Huxman T, Chorover J. Mineral nutrient mobilization by plants from rock: influence of rock type and arbuscular mycorrhiza. Biogeochemistry. 2015;124(1):187-203. https://doi.org/ 10.1007/s10533-015-0092-5

41. Morte A, Navarro-Ródenas A, Nicolás E. Physiological parameters of desert truffle mycorrhizal Helianthemun almeriense plants cultivated in orchards under water deficit conditions. Symbiosis. 2010;52(2):133-39. https://doi.org/10.1007/ s13199-010-0080-4

42. Augé RM. Water relations, drought and vesicular-arbuscular mycorrhizal symbiosis. Mycorrhiza. 2001; 1;11(1):3-42. https://doi.org/10.1007/s005720100097

43. Amiri R, Nikbakht A, Etemadi N. Alleviation of drought stress on rose geranium [Pelargonium graveolens (L.) Herit. ] in terms of antioxidant activity and secondary metabolites by mycorrhizal inoculation. Scientia Horticulturae. 2015;14(197):373-80. https://doi.org/10.1016/ j.scienta.2015.09.062

44. Wu QS, Zou YN, Huang YM. The arbuscular mycorrhizal fungus, Diversispora spurca ameliorates effects of waterlogging on growth, root system architecture and antioxidant enzyme activities of citrus seedlings. Fungal Ecology. 2013;6(1):37-43.

https://doi.org/10.1016/j.funeco.2012.09.002

45. Sperdouli I, Moustakas M. Interaction of proline, sugars and anthocyanins during photosynthetic acclimation of Arabidopsis thaliana to drought stress. Journal of Plant Physiology. 2012;169(6):577-85. https://doi.org/10.1016/ j.jplph.2011.12.015

46. Sharma S, Villamor JG, Verslues PE. Essential role of tissuespecific proline synthesis and catabolism in growth and redox balance at low water potential. Plant Physiology. 2011;157(1):292-304. https://doi.org/10.1104/pp.111.183210

47. Aroca R, Porcel R, Ruiz-Lozano JM. Regulation of root water uptake under abiotic stress conditions. Journal of Experimental Botany. 2012;1;63(1):43-57. https://doi.org/10.1093/ jxb/err266

48. Zhang Z, Zhang J, Huang Y. Effects of arbuscular mycorrhizal fungi on the drought tolerance of Cyclobalanopsis glauca seedlings under greenhouse conditions. New Forests. 2014;45(4):545-56. https://doi.org/10.1007/s11056-014-9417-9

49. Bacon CW, White JF. Functions, mechanisms and regulation of endophytic and epiphytic microbial communities of plants. Symbiosis. 2016;68(1-3):87-98. https://doi.org/ 10.1007/s13199-015-0350-2

50. Huang YM, Zou YN, Wu QS. Alleviation of drought stress by mycorrhizas is related to increased root $\mathrm{H} 2 \mathrm{O} 2$ efflux in trifoliate orange. Scientific Reports. 2017 Feb 8;7(1):1-9. https://doi.org/10.1038/srep42335 
51. Akram NA, Shafiq F, Ashraf M. Ascorbic acid-a potential oxidant scavenger and its role in plant development and abiotic stress tolerance. Frontiers in Plant Science. 2017 Apr 26;8:613. https://doi.org/10.3389/fpls.2017.00613

52. Sharma P, Jha AB, Dubey RS, Pessarakli M. Reactive oxygen species, oxidative damage, and antioxidative defense mechanism in plants under stressful conditions. Journal of Botany. 2012;2012. https://doi.org/10.1155/2012/217037

53. Li J, Wang Y, Pritchard HW, Wang X. The fluxes of $\mathrm{H} 2 \mathrm{O} 2$ and 02 can be used to evaluate seed germination and vigor of Caragana korshinskii. Planta. 2014;239(6):1363-73. https://doi.org/10.1007/s00425-014-2049-7

54. Ruiz-Sánchez M, Aroca R, Muñoz Y, Polón R, Ruiz-Lozano JM. The arbuscular mycorrhizal symbiosis enhances the photosynthetic efficiency and the antioxidative response of rice plants subjected to drought stress. Journal of Plant Physiology. 2010;167(11):862-69. https://doi.org/10.1016/ j.jplph.2010.01.018

55. Gharibi S, Tabatabaei BE, Saeidi G, Goli SA. Effect of drought stress on total phenolic, lipid peroxidation and antioxidant activity of Achillea species. Applied Biochemistry and Bio- technology. 2016;178(4):796-809. https://doi.org/10.1007/ s12010-015-1909-3

\section{Additional information}

Peer review information: Plant Science Today thanks Sectional Editor and the other anonymous reviewers for their contribution to the peer review of this work.

Reprints and permissions information is available at https://horizonepublishing.com/journals/index.php/PST/open_access_policy

Publisher's Note: Horizon e-Publishing Group remains neutral with regard to jurisdictional claims in published maps and institutional affiliations.

To cite this article: Tyagi J, Shrivastava N, Sharma A K, Varma A, Pudake R N. Effect of Rhizophagus intraradices on growth and physiological performance of Finger millet (Eleusine coracana L.) under drought stress. Plant Science Today. 2021;8(4):912-923. https://doi.org/10.14719/pst.2021.8.4.1240

Plant Science Today, published by Horizon e-Publishing Group, is covered by Scopus, Web of Science, BIOSIS Previews, Clarivate Analytics, etc. See https://horizonepublishing.com/journals/index.php/PST/indexing_abstracting 